\title{
Fetal Properties in Red Blood Cells of Newborn Infants
}

\author{
M. GAHR, ${ }^{(34)}$ H. MEVES, AND W. SCHRÖTER \\ Universitäts-Kinderklinik Göttingen, West-Germany
}

\begin{abstract}
Summary
In order to identify the fetal features in neonatal erythrocytes, cord blood was separated into seven fractions of varying specific density. Cell age in the single fractions was ascertained by means of reticulocyte count, glutamic-oxalacetic transaminase activity, and hemoglobin $F$ concentration. The same procedures were used with blood of adults. With the exception of the fraction of neonatal blood with the highest specific density, the blood from neonates and adults correlated well for cell age and specific density. The highest specific density fraction of neonatal blood was found to contain a higher proportion of younger cells.

The comparison of enzyme activities in the single fractions between neonates and adults showed that a high activity of glucose6-phosphatedehydrogenase and enolase and a low activity of phosphofructokinase are typical fetal signs of neonatal cells.
\end{abstract}

\section{Speculation}

The changing constitution of red blood cells $(\mathrm{RBC})$, which were observed during the first months of life may be a part of the differentiation process. Due to their good accessibility and their relatively simple metabolism, erythrocytes from neonates can serve as a good in vivo model that helps to clarify the process of differentiation.

As a part of the differentiation process the properties distinguishing neonatal from adult erythrocytes (17) are lost during the first months of life and are replaced by the corresponding adult properties. To examine the factors and mechanisms that govern the process of differentiation, it is first necessary to define the fetal properties of neonatal red cells.

Due to the shorter lifespan of fetal erythrocytes and the higher proportion of young cells in blood of newborn infants, direct comparison with adult red cells is not possible. Therefore, in this study, a fractionation method was used that separated blood in subpopulations of cell age to better define the typical fetal signs of neonatal red cells.

\section{MATERIALS}

Ficoll was purchased from Pharmacia (27). Sodium metrizoate (Triosil) was the product of Nyegaard (28). Enzymes were obtained from Boehringer (29). All other chemicals were from Merck (30).

\section{METHODS}

\section{SEPARATION OF ERYTHROCYTES INTO FRACTIONS OF DIFFERENT} AGE

To obtain fractions of different cell age, erythrocytes were separated by isopycnic gradient centrifugation using the method of Turner et al. (24). Erythrocytes were washed twice in cold isotonic saline, the white cell layer being carefully removed after each wash. Erythrocytes, $0.35 \mathrm{ml}$, which were suspended in an equal volume of isotonic saline, were layered on top of a gradient of seven different mixtures of $40 \%(\mathrm{w} / \mathrm{v})$ Ficoll and $34 \%$ Triosil with specific densities of $1.100,1.105,1.110,1.115,1.120,1.130$ and $1.140 \mathrm{~g} / \mathrm{ml}$. Separation was accomplished by centrifugation in a Sorvall centrifuge with a swinging-out rotor (HB 4) at $2^{\circ} \mathrm{C}$ for $2 \mathrm{hr}$ at $25,000 \times \mathrm{g}$ in polyallomer tubes with $95 \mathrm{~mm}$ length and $12 \mathrm{~mm}$ diameter. The fractions obtained were carefully aspirated and washed three times with cold isotonic saline. All procedures were done at $2-4^{\circ} \mathrm{C}$

\section{DETERMINATION OF ENZYME ACTIVITIES}

Hemolysates for determination of enzyme activities were prepared by hypotonic lysis of the erythrocytes in a solution containing $2.7 \mathrm{mM}$ EDTA, $7 \mathrm{mM}$ mercaptoethanol and $10 / \mu \mathrm{M}$ NADP. After centrifugation $\left(6000 \times \mathrm{g}, 10 \mathrm{~min}, 2^{\circ} \mathrm{C}\right)$, the supernatant was immediately used for determination of enzyme activities. The activity of hexokinase (Hk), glucose-6-phosphatedehydrogenase (G-6-PD), and 6-phosphogluconatedehydrogenase were assayed as described by Beutler (3). Enolase (En) and phosphofructokinase (PFK) activity were determined according to Schröter (22). Glutamic-oxalacetictransaminase (GOT) activity was determined with the Boehringer-testkit. All these procedures were carried out on an Eppendorf-spectrophotometer at $37^{\circ} \mathrm{C}$. Catalytic activity was expressed in $\mu$ moles of product formed per $\mathrm{min} / \mathrm{g}$ hemoglobin (I.U.).

\section{OTHER PROCEDURES}

Hemoglobin concentration was determined by the cyanmethemoglobin method. Cell counts were performed on a Coulter Counter, model FN. Reticulocyte counts were done after staining with $1 \%$ brillantcresylblue. Hemoglobin $F$ concentration was measured using the method of Betke et al. (2).

\section{SOURCE OF BLOOD SAMPLES}

Adult blood was obtained from healthy male laboratory personnel. Neonatal blood was obtained from the placenta directly after birth. These were uncomplicated term births as indicated by length of gestation, weight, length, head circumference, and clinical condition.

\section{RESULTS}

DISTRIBUTION OF ERYTHROCYTES FROM ADULTS AND NEONATES WITHIN THE DENSITY GRADIENT

The relative distribution of cells between different layers was determined by measuring the hemoglobin content of each layer. This value was expressed as a percent of the total hemoglobin recovered from the gradient. According to Turner et al. (24), adult erythrocytes yielded a normal distribution (Fig. 1), i.e., most of the erythrocytes were confined to the layer with the specific density of 1.105 or $1.115 \mathrm{~g} / \mathrm{ml}$ (Fig. 2). This pattern of distribution was not seen in neonatal erythrocytes, rather there was a consistent "shift to the right" indicating that the layer with the maximum 


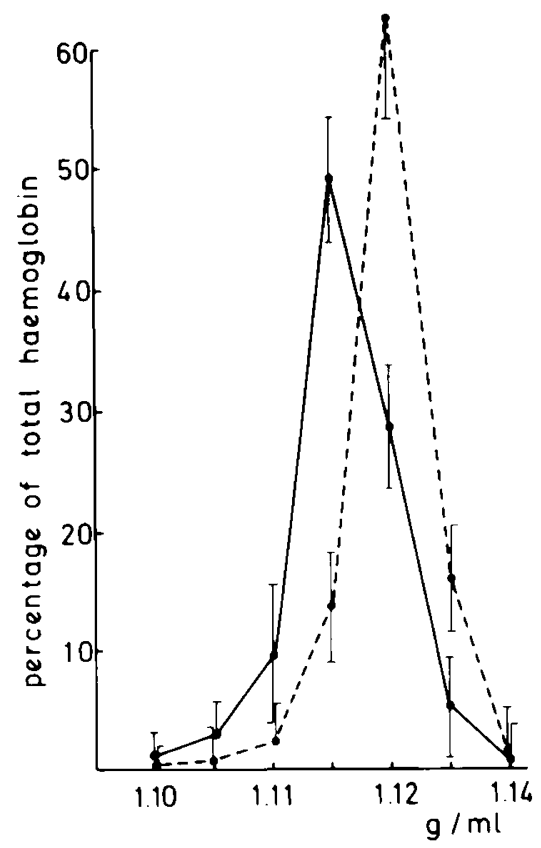

Fig. 1. Distribution of erythrocytes (indicated by the hemoglobin content) in the single layers of the gradient. adults $(N=9)$. The vertical bars represent the mean $\pm \mathrm{SD}$.

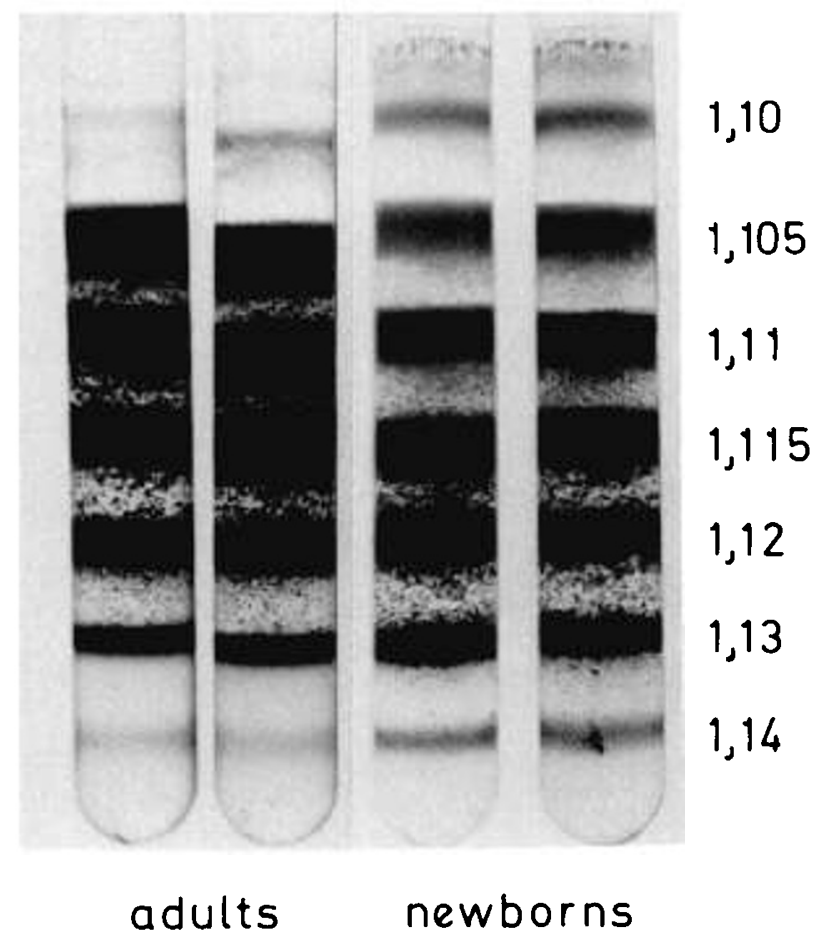

Fig. 2. Separation of erythrocytes in fractions of different specific densities by a Ficoll/Triosil gradient. For experimental details, see Methods.

number of erythrocytes had a higher specific density than in adult cells. Using erythrocytes from preterm infants, this shift to the right was even more pronounced (not shown). With the technique used in these experiments, the erythrocytes were separated into different fractions according to the specific density of the cells. Therefore, the layers of the gradient with high specific density contain erythrocytes with small volume and high hemoglobin per $\mathrm{ml}$ of cells (Fig. $3 \mathrm{a}+\mathrm{c}$ ). The mean hemoglobin content per cell remains fairly constant (Fig. 3b). Neonatal erythrocytes do not differ from adult cells in this respect. It can be seen that neonatal erythrocytes have a higher volume and a higher hemoglobin content per cell than adult erythrocytes.

\section{RELATIONSHIP BETWEEN CELL AGE AND SPECIFIC DENSITY}

To correlate the mean density of the single layers of the gradient with the mean cell age, the relative numbers of reticulocytes in each fraction were determined. The results are shown in Figure 4. In adults, the layers of the gradient with high specific density do not contain any reticulocytes. In neonatal erythrocytes, the percent of reticulocytes fell with increasing specific density except in the last layer $(1.140 \mathrm{~g} / \mathrm{ml})$, where the relative number of reticulocytes increased.

As was shown by Sass et al. (21), the GOT activity correlates well with red cell age. The GOT activity in neonatal and adult erythrocytes after separation is shown in Figure 5. In general, GOT activity declines with increasing specific density. Neonatal erythrocytes, however, exhibit a GOT activity in the layer with the highest density which does not represent the lowest value.

The hemoglobin $F$ concentration in neonatal erythrocytes should be higher in "old" cells than in the "younger" ones. The neonatal erythrocytes with low specific density have the lowest hemoglobin F concentration (Fig. 6). With increasing specific density, the proportion of hemoglobin $F$ becomes higher. In the layer with erythrocytes of the highest specific density, however, the hemoglobin $\mathrm{F}$ concentration is slightly lower than that of the preceding layer.

\section{ENZYME ACTIVITIES IN ERYTHROCYTES OF DIFFERENT SPECIFIC DENSITIES IN ADULTS AND NEWBORN INFANTS}

The activities of Hk, G-6-PD, 6-phosphogluconatedehydrogenase, and En of neonatal erythrocytes are higher in all layers than in the corresponding fractions of adult cells (Fig. 7 a-d). PFK activity of newborn erythrocytes, however, is lower in all layers of the gradient than in those of adult cells (Fig. 7e). Except for PFK and En, all enzyme activities measured falls corresponding to increasing specific density of the cell fractions, in adults as well as in neonates (Fig. $7 \mathrm{a}-\mathrm{c}$ ). This decrease of enzyme activity with increase in specific density is more pronounced in neonatal than in adult erythrocytes.

As a measure for the alteration of enzyme activity with increasing density, the ratio between the activities of the youngest and of the oldest cells was calculated (Table 1). The ratios of En were not different in either type of erythrocyte. In neonatal erythrocytes, the ratio of PFK is 2.16 in contrast to a ratio of 1.11 in adult erythrocytes.

\section{DISCUSSION}

In contrast to the widely used method to obtain young and old erythrocytes (the $10 \%$ top and bottom cells after ultracentrifugation $(9,20)$ ), the procedure used in these experiments allows separation of small volumes of blood. This is an important factor in neonatal hematology. Alternatively, the technique of Turner $e t$ al. can be modified to separate larger volumes of erythrocytes.

With adult erythrocytes, this separation procedure seems to separate the cells according to cell age. Mean corpuscular volume becomes lower and mean corpuscular hemoglobin concentration higher with the increasing specific density of the layers of the gradient. This has been found by other authors as well (Cohen $e t$ al. (5), Piomelli et al. (19)), and seems to be due to water loss during cell aging. Some authors believe that portions of the membrane are lost during cell aging and that the cell becomes denser in this way (5). The distribution of reticulocytes and the GOT activity in the single layers confirmed that this technique offers a separation according to cell age. Sass et al. (21), have shown that GOT activity provides the most sensitive reflection of cell age.

In neonatal erythrocytes, there is obviously no strong correlation between specific density and cell age. The layer of the gradient with the highest density $(1.140 \mathrm{~g} / \mathrm{ml})$ contains some reticulocytes, 

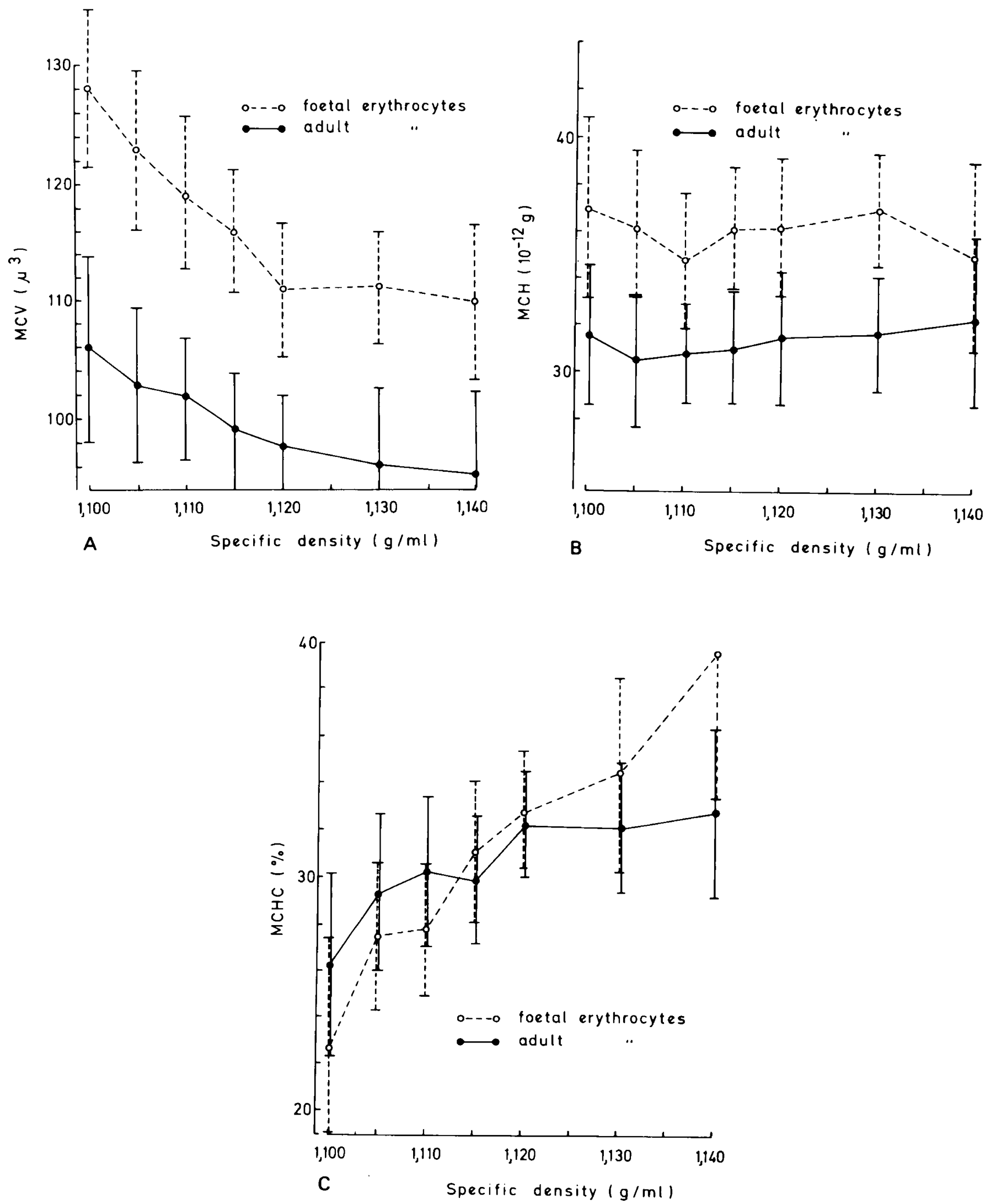

Fig. 3. (a,b,c) $\mathrm{MCV}, \mathrm{MCH}$, and $\mathrm{MCHC}$ in the single layers of the gradient. For explanation, see Figure 1.

the GOT activity increases slightly and the hemoglobin F concentration, which is low in young cells and increases with higher densities, diminishes in the last layer. So the fraction of neonatal erythrocytes with a high specific density contains not only old cells, but must also include some younger cells. For all other fractions of neonatal blood, however, a correlation between cell age and density can be supposed.

The results described here confirm the observations of Turner et al. (24) that the distribution of adult erythrocytes within the gradient is similar to an ideal normal distribution. Erythrocytes of 


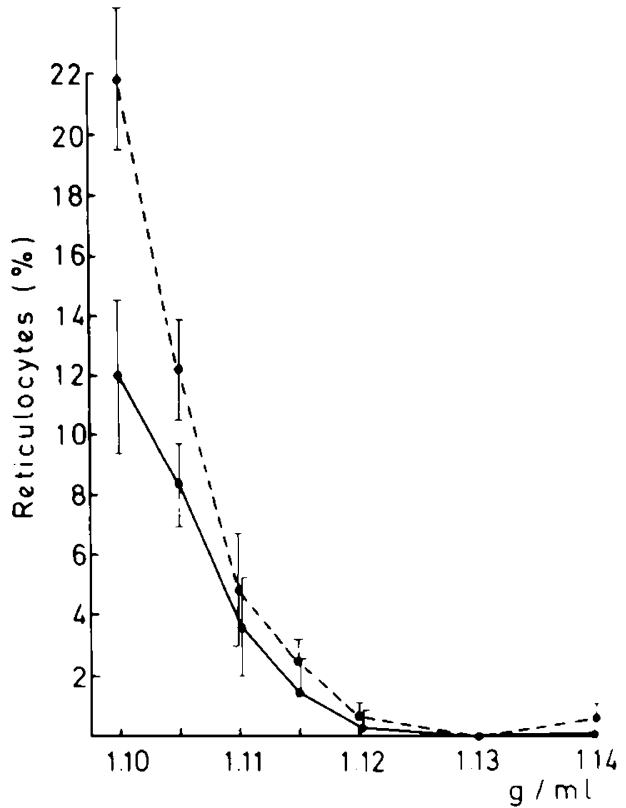

Fig. 4. Reticulocytes in the single layers of the gradient. For explanation, see Figure 1.

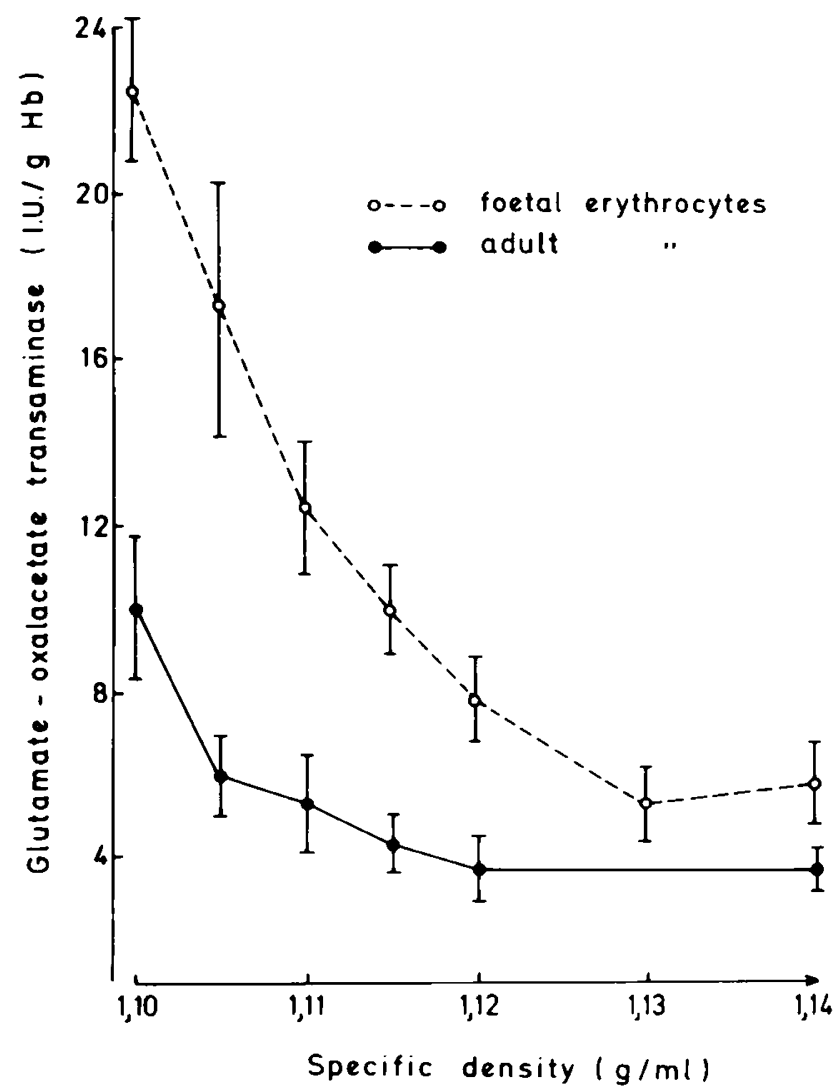

Fig. 5. GOT activity in the single layers of the gradient. For explanation, see Figure 1.

neonates, however, are not distributed symmetrically after centrifugation, but are found more frequently in the fractions with higher densities. This shift to the right may reflect the fact that the lifespan of the erythrocytes is not constant during prenatal development (Garby et al. (8), Pearson (18)). If one assumes that the lifespan of erythrocytes during fetal development becomes gradually longer, the layers of the gradient that probably contain the

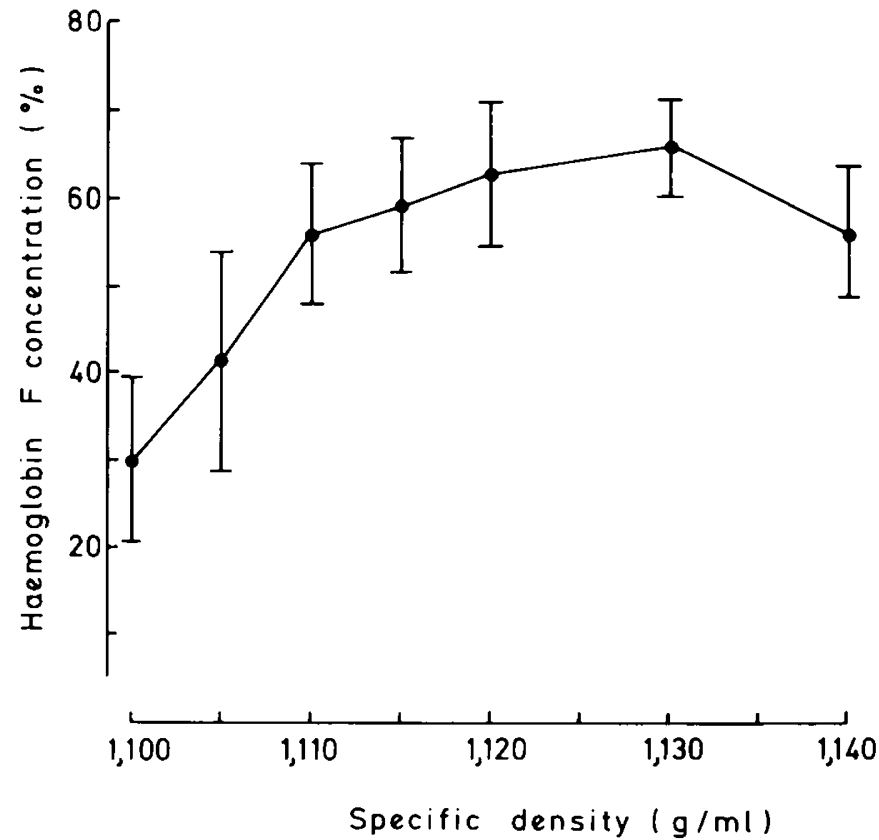

Fig. 6. Hemoglobin $\mathrm{F}$ concentration in the single layers of the gradient with blood of newborn infants.

younger cells (= low density) should contain more cells than the fractions with high density.

The ratios of enzyme activities between the youngest and the oldest cells demonstrate that of the enzymes examined Hk exhibits the largest decrease during cell aging in neonatal blood. In adult blood, however, GOT shows the greatest decline in accordance with the results of Sass et al. (21). Komazawa and Oski (12) calculated ratios of enzyme activities between young and old cells of newborn infants and adults. With neonatal blood they obtained lower ratios for Hk $(2.69 \pm 0.72)$ and higher ones for PFK and En $(1.70 \pm 0.24$ and $1.03 \pm 0.07)$ than are reported in this paper. This is possibly a result of their separation method that is not as selective as the technique used in this study.

Due to the shorter lifespan and the more active erythropoiesis, the mean cell age of neonatal blood is lower. Therefore, enzyme activities in neonatal erythrocytes have to be compared with cell populations of similar age distribution. Most authors compared neonatal erythrocytes with blood of comparable reticulocytosis (Konrad et al. (13), Gahr et al. (6), Oski (16)). The number of reticulocytes, however, is a very uncertain marker for the mean cell age of the whole cell population, for reticulocytes lose their substantia granulofilamentosa after 2 days; later on the young cells cannot be distinguished from old cells by visual methods. In contrast, separation into fractions of different cell age allows the behavior of enzyme activity to be continuously followed during cell aging.

The experiments did show that the PFK activity of neonatal erythrocytes is lower in all fractions than in any fraction of adult cells (similar results were published recently by Travis and Garvin (23)). Otherwise, En and G-6-PD activity were higher in all layers of neonatal blood than in the fraction of adult cells with the highest activity. From these results it can be concluded that a high activity of G-6-PD and En and a low activity of PFK are typical distinguishing signs of neonatal cells.

The rate of decline of PFK activity in neonatal erythrocytes indicates that this enzyme has some features that are different from those in adult erythrocytes. In contrast to Whaun and Oski (26) who could not find any differences between PFK of unfractionated red cells of adults and neonates, Kahn et al. (10) and Vora and Piomelli (25) were able to demonstrate some pecularities of neonatal PFK. Kahn et al. (10) found that PFK of old cells from neonates was less neutralized by antimuscle PFK serum and 

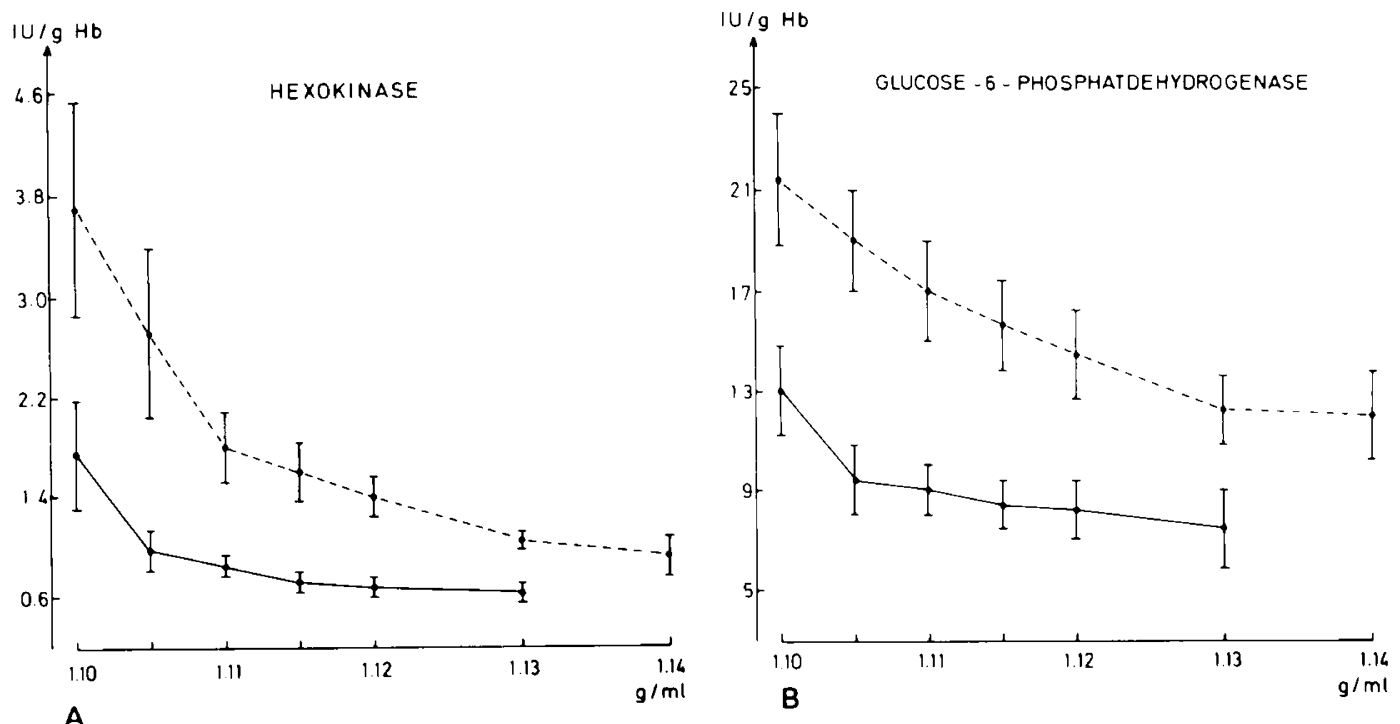

A
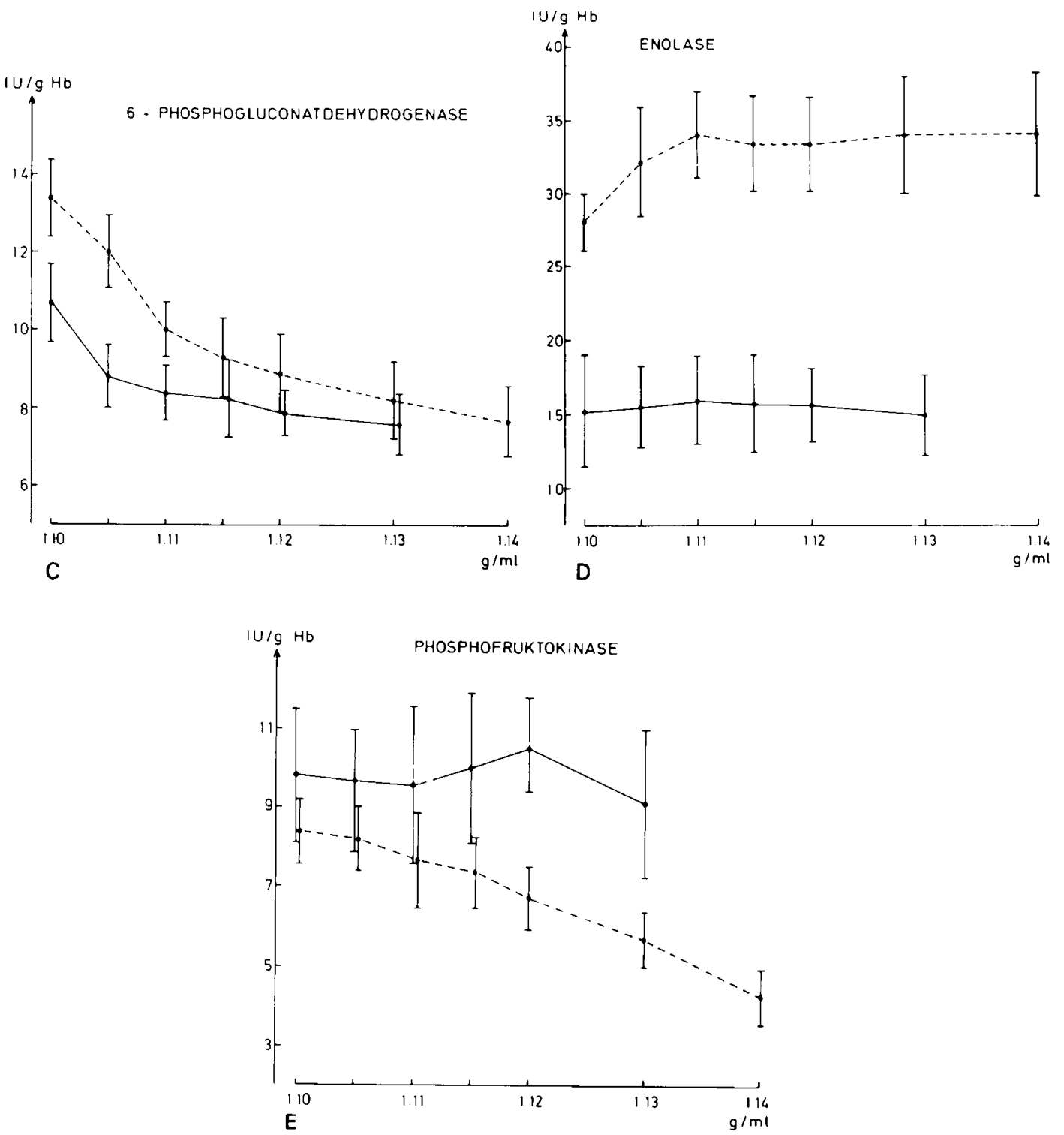

Fig. 7. (a-e) Enzyme activities in the single layers of the gradient. For explanation, see Figure 1. 
Table 1. Ratios of enzyme activities between young (= specific density $1.10 \mathrm{~g} / \mathrm{ml}$ ) and old (= specific density $1.14 \mathrm{~g} / \mathrm{ml}$ ) erythrocytes from newborn infants and adults. The means $\pm S D$ are given.

\begin{tabular}{lcc}
\hline & $\begin{array}{c}\text { Newborn infants } \\
(N=9)\end{array}$ & $\begin{array}{c}\text { Adults } \\
(N=9)\end{array}$ \\
\hline GOT & $3.98 \pm 0.81$ & $2.65 \pm 0.52$ \\
Hk & $4.01 \pm 0.99$ & $2.17 \pm 0.26$ \\
G-6-PD & $1.77 \pm 0.28$ & $1.72 \pm 0.31$ \\
6-phosphogluconate & $1.77 \pm 0.18$ & $1.4 \pm 0.18$ \\
$\quad$ dehydrogenase & & \\
En & $0.8 \pm 0.06$ & $1.05 \pm 0.11$ \\
PFK & $2.16 \pm 0.5$ & $1.11 \pm 0.17$ \\
\hline
\end{tabular}

more inhibited by ATP than the enzyme from adult erythrocytes. They speculated that there exists a fetal type of PFK that is deficient in a subunit. That neonatal PFK is composed of subunits was also confirmed by the work of Vora and Piomelli (25). They have demonstrated that PFK from cord blood was eluted in two peaks from DEAE-Sephadex, whereas only one peak is seen with adult erythrocytes.

The differences in isoenzyme distribution between neonatal and adult erythrocytes were also observed in En (1). The difference in catalytic activity between neonatal and adult red cells (PFK and En) may reflect the difference in the isoenzyme distribution. But an enzyme whose activity is not divergent from that of adult cells may also exhibit a different pattern of isoenzyme than is the case with Hk (7).

The process of differentiation that was observed in red blood cells in the first year of life is probably due to the disappearance of "fetal" isoenzymes and the gradual appearance of "adult" isoenzymes. A similar process is known to occur with the globin chains of the hemoglobin, which also can be considered to be "isoenzymes."

\section{REFERENCES AND NOTES}

1. Bartels, H., and Vogel, I.: Isoenzyme der Enolase in Erythrozyten Neugeborener und Erwachsener. Z. Kinderheilk, 111: 247 (1971).

2. Betke, K., Marti, H. R., and Schlicht. I.: Estimation of small percentages of foetal haemoglobin. Nature, 184: 1877 (1959).

3. Beutler, E.: Red Cell Metabolism. A Manual of Biochemical Methods. Ist ed. (Grune and Stratton, New York, 1971).

4. Brok. F., Ramot, B., Zwang, E., and Danon, D.: Enzyme activities in human red blood cells of different age groups. Israel J. Med. Sci., 2: 291 (1966).

5. Cohen, N. S., Ekholm, J. E., Luthra, M. G., and Hanahan, D. J.: Biochemical characterization of density-separated human erythrocytes. Biochim. Biophys. Acta, 419: 229 (1976).

6. Gahr, M., Jentsch, E., and Schröter, W.: Fetal erythropoiesis and dyserythropoiesis in juvenile chronic myeloid leukaemia. Acta Haematol., 56: 39 (1976)

7. Gahr, M., and Schröter, W.: Hexokinase in erythrocytes of newborn infants and adults: Isolation and characterization of the isoenzymes. Pediatr. Res., (Abstract) 12: 66 (1978).

8. Garby, L., Sjolin. S., and Viulle, J. C.: Studies on the erythrokinetics of infancy.
V. Estimation of the life span of red cells in the newborn. Acta Paediatr. Scand., 53: 165 (1964).

9. Hoffman, J. F.: On the relationship of certain erythrocyte characteristics to their physiological age. J. Cell. Comp. Physiol., 51: 415 (1958).

10. Kahn, A., Boyer, C., Cottreau, D., Marie, J., and Boivin, P.: Immunologic study of the age related loss of activity of six enzymes in the red cells from newborn infants and adults. Evidence for a foetal type of erythrocyte phosphofructokinase. Pediatr. Res., 11: 271 (1977)

11. Keitt, A. S.: Reduced nicotinamide adenine dinucleotide-linked analysis of 2,3diphosphoglyceric acid: Spectrophotometric and fluorometric procedures. J. Lab. Clin. Med., 77: 470 (1971).

12. Komazawa, M., and Oski, F. A.: Biochemical characteristics of "young" and "old" erythrocytes of the newborn infant. J. Pediatr. 87: 102 (1975).

13. Konrad, P. N., Valantine, W. N., and Paglia, D. E.: Enzymatic activities and glutathione content of erythrocytes in the newborn: comparison with red cells of older normal subjects and those with comparable reticulocytosis. Acta Haematol., 48: 193 (1972).

14. Lamprecht. W., and Trautschold, J.: Adenosin-5-triphosphat-Bestimmung mit Hexokinase und Glucose-6-phosphatdehydrogenase. In: H. V. Bergmeyer: Methoden der enzymatischen Analyse. p. 2024 (Verlag Chemie, Weinheim Bergstraße, 1970).

15. Lichtman, M. A.: Does ATP decrease exponentially during red cell aging? Nouv. Rev. Franc. d'Hêmatol., 15: 625 (1975).

16. Oski, F. A.: Red cell metabolism in the newborn infant. V. Glycolytic intermediates and glycolytic enzymes. Pediatrics, 44: 84 (1969).

17. Oski, F. A., and Komazawa, M.: Metabolism of the erythrocytes of the newborn infant. Semin. Hematol., 12: 209 (1975).

18. Pearson, H. A.: Life-span of the fetal red blood cell. J. Paediatr., 70: 166 (1967).

19. Piomelli, S., Lurinsky, G., and Wassermann, L. R.: The mechanism of red cell aging. I. Relationship between cell age and specific gravity evaluated by ultracentrifugation in a discontinuous density gradient. J. Lab. Clin. Med., 69; 659 (1967)

20. Rigas, D. A., and Koler, R. D.: Ultracentrifugal fractionation of human erythrocytes on the basis of cell age. J. Lab. Clin. Med., 58: 242 (1961).

21. Sass, M. D., Vorsanger, E., and Spear, P. W.: Enzyme activity as an indicator of red cell age. Clin. Chim. Acta, 10: 21 (1964).

22. Schröter, W.: Erythrocyte Enzymes. In: Curtius and Roth: Clinical Biochemistry. p. 1178 (De Gruyter, Berlin, 1974).

23. Travis, S. F., and Garvin, J. H.: In vivo lability of red cell phosphofructokinase in term infants: the possible molecular basis of the relative phosphof ructokinase deficiency in neonatal red cells. Pediatr. Res., 11: 1159 (1977).

24. Turner, B. M., Fisher, R. A., and Harris, H.: An association between the kinetic and electrophoretic properties of human purine-nucleoside-phosphorylase isoenzymes. Eur. J. Biochem. 24: 288 (1971).

25. Vora, S.. and Piomelli, S.: A fetal isozyme in phosphofructokinase in newborn erythrocytes. Pediatr. Res., (Abstract) 11: 483 (1977).

26. Whaun, J. M., and Oski, F. A.: Characteristics of red cell phosphofructokinase (PFK). Studies of erythrocytes from newborn infants and adults. Clin. Res., (Abstract) 27: 603 (1969)

27. Pharmacia, Uppsala, Sweden.

28. Nyegaard, Oslo, Norway.

29. Boehringer, Mannheim. West-Germany.

30. Merck, Darmstadt, West-Germany.

31. Informed consent was obtained from the parents of all infants included in this study.

32. The authors thank Mrs. F. Rüger and Mrs. M. Schmidt for their technical assistance.

33. This research was supported by the Deutsche Forschungsgemeinschaft (Ga 148) 2).

34. Requests for reprints should be addressed to: M. Gahr, M. D., UniversitätsKinderklinik Göttingen. Humboldtallee 38, D-3400 Göttingen, West-Germany.

35. Received for publication June 12, 1978

36. Accepted for publication November 27, 1978 